\title{
A LITERATURE REVIEW ON THE AL-HADIS AS SOURCE OF HUMAN MORAL EDUCATION
}

Firmansyah $^{\text {a) }}$

a) Lecturer and Lecturer of STAI Mempawah, Mempawah Regency, West Kalimantan

\begin{abstract}
Scope: The formation of good character that can produce an Islamic generation is not only a human being with high knowledge but also the generation of Islam includes individuals with an Islamic spirit to get happiness, progress, strength and determination. All of this is the goal of moral education. Objective: The main objective of this study is to study literature reading literature from a variety of articles, national and international journals, books and other literature and be reviewed according to the study so as to answer this Islamic research question. Method: Examining a variety of hadith literature as a source of teaching materials for the morality of the Islamic ummah in achieving life goals; prosperous and happy in the world and hereafter. The source is from a variety of reading journals and publications both at home and abroad about the virtues of al-hadith as the basic foundation of moral education so that people can answer this research problem. Finding: The findings include some of the most authentic traditions of the Prophet's companions as well as quotations of the verses of the Koran are very relevant to the citation of traditions as a guide to the moral education of humanity especially the Muslim generation. Recommendation: It is proper for moral education to be developed and developed in every community environment, both Muslims and non-Muslims, making the Prophet as the right human figure to be a role model because of the character that is reflected in each of His life.
\end{abstract}

Keywords: Moral Education, Ummah Education, and Hadith

\section{A. Introduction}

Morals is a pillar that sustains a good relationship between the servant with God (vertical) and fellow human beings (harizontal). Good character will be present in humans with the process of experimentation and habituation. Good character will emerge from a person by instilling moral education that has been exemplified by the Prophet. Western countries claim the moral education they teach is an education that they believe has merit. But the moral education they teach is not all true and in accordance with the moral education taught by the Prophet. While moral education taught by Islam is something that is true and has no shortcomings. Moral education brought about by Islam comes directly from Allah conveyed to the Prophet Muhammad through the angel Gabriel to the Qur ' an and Sunnah to the people Raasulullah.

The Prophet as the best example of giving Moral knowledge to his family and friends. So that people close to the Prophet Muhammad SAW were able to have high morals before other 
people and noble morals before God. As good Muslims and have faith in Allah, our every step should be the implementation and exemplary noble character possessed by the Prophet.

The view that life on a moral basis is ancient and out of date and far from modernity must be removed from our thinking. Moral decline that occurs throughout the end of the world should be a concern for all people. Humans should be aware of and return to their nature as human beings created by God with noble morals. The most perfect person of faith is the one who is morally good. The morality taught in this noble Islam will bring the Ummah to survive in this world and the hereafter.

From the explanation above, it is clear that morals make a person's dignity high and noble. Likewise, in a country if the people have good character, then the height and dignity of the country will be faced by other countries. It is ironic when the country's formal schools or educational institutions in which education and moral application are no longer a priority for success in the learning process. So it is not surprising that tertiary education graduates with very high qualifications but highly doubt the quality of morals and faith. Lately, according to the mass media report, the moral damage of students has reached a very alarming peak. For example, brawls among students, criminal cases involving students such as promiscuity and promiscuity and the world of institutions involving students. Therefore, the noble character must be planted for children from the beginning and get used to train them to have good morals. For this reason, both parents have a big role in preparing their children to always have good morals. based on Islamic teachings.

The study in this study is a literature review by collecting various kinds of national and international journal articles, books and other literature and examined according to the study to be discussed. ${ }^{1}$ A series of literature reviews of hadith as a source of teaching material for the morality of the Islamic ummah in achieving the goals of prosperous and happy life in the world and the hereafter. Literature sources are from various readings of journals and publications at home and abroad about the virtues of al-hadith as the basic foundation of moral education for the ummah so that it can answer this research problem.

\section{B. Understanding Morals}

The word morals comes from the Arabic khuluq which is plural akhlaq. According to language, morality is temperament, character, and religion. The word contains aspects of conformity with the words khlq which means "event", and is closely related to the word khaliq which means "creator" and makhluq which means "who was created". 2 There are two approaches used to define morals, namely the linguistic approach (linguistic) and the

\footnotetext{
${ }^{1}$ Aslan, "Pumping Teacher dalam Tantangan Pendidikan Abad 21" 2, nomor 2 (2017): 89-100.

${ }^{2}$ Rasihon Anwar, Akhlak Tasawuf (Bandung: Pustaka Setia, 2010), 11.
} 


\section{Firmansyah}

terminological approach (terminology). From the linguistic point of view, morals are derived from the Arabic word, namely isim masdhar (infinitive form) from the words akhlaqa , yakhliqu, ikhlaqan, according to the scales (wazan) of the mazid af ' ala, yaf ' ilu, if ' alan which means al Sajiyyah (behavior), nature, basic character), al ' adat (habits, custom), al maru ' ah (good civilization) and aldin (religion). ${ }^{3}$

The definition of morals according to moral scholars, among others, as follows:

According to Ibn Maskawaih (941-1030 AD)

$$
\text { حال للنفس داعية لها المى افعالها من غير فكر ولا روية ـ وهذه الحال تنقسم الم قسمين : منها ما يكون طبعيا من اصل الزاج }
$$

The state of the soul that encourages it to do actions without first considering the mind. This state is divided into two, some are derived from the original character ... some are obtained from repetitive habits. It may be, at first the action was through thought and consideration, then done continuously, then become a talent and character. ${ }^{4}$

Imam Al Ghazali ( 1055-11ll AD) in Ihya Ulumuddin stated:

$$
\text { هيئة راسخة في النفس تصدر عنها الافعال بيسر وسهولة من غير حاجة المى فكر وروية }
$$

Morals are the strengths (traits) embedded in the soul that encourage spontaneous actions without the consideration of the mind "5

In $\mathrm{Mu}$ ' jam $\mathrm{Al}$ Wasith, Ibrahim Anis said that morals are:

$$
\text { حال للنفس راسخة تصدر عنها الاعمال من خير او شر من غير حاجة الى فكر ورؤية }
$$

"The nature that is implanted in the soul, through which all kinds of actions are born, without the need for thought and consideration"

From the above understanding illustrates that behavior is a form of personality without being made-up or spontaneous or without any outside encouragement. If good according to the view of reason and religion, spontaneous actions are called good morals (alakhlakul karimah/ al akhlakul mahmudah ), otherwise if spontaneous actions are bad is called al akhlakul Mazmumah. ${ }^{7}$

\footnotetext{
${ }^{3}$ Abudin Nata, Akhlak Tasawuf (Jakarta: Rajawali Pers, 2012), 1.

${ }^{4}$ Anwar, Akhlak Tasawuf, 1.

${ }^{5}$ Anwar, 13.

${ }^{6}$ Ibrahim Anis, Al Mu'jam Al Wasith (Mesir: Dar Al Ma'arif, 1972), 202.

${ }^{7}$ Anis, 15.
} 


\section{The Position and Urgency of Hadith as a Source of Islamic Education}

Muslims, without exception, have understood that the tradition is one of the sources of Islamic teachings, he occupies an important position after the Qur ' an. The obligation to follow the same tradition of the Muslims is obligatory to follow the Qur ' an. Therefore, the Islamic ummah no longer doubts that the Hadith is a reference in Islamic education sciences. Hadith is not only used as a tool to explore Islamic laws but also as an inspiration for Islamic education after the Koran. This is evidenced by quite a number of traditions that explain the view of the Prophet about how to educate the Islamic generation to become a noble community.

The following proposition states that the role is very urgent for every Muslim to hold fast to the Hadith:

\section{Proposition Qur ' an}

In the Qur'an abundant paragraph which stresses the obligation to follow God coupled with obedience to follow His Messenger, such as the Word of God following:

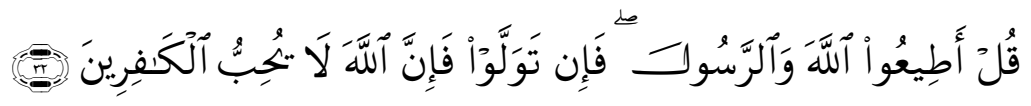

Meaning: Say: "Obey Allah and His Messenger; if you turn away, then surely Allah does not like unbelievers". (Ali ' Imran: 32 )

In another verse it is also explained about the obligation to accept what is conveyed by Rasulullah SAW, as the Word of Allah SWT in Surah Al Hasyr verse 7 Allah says:

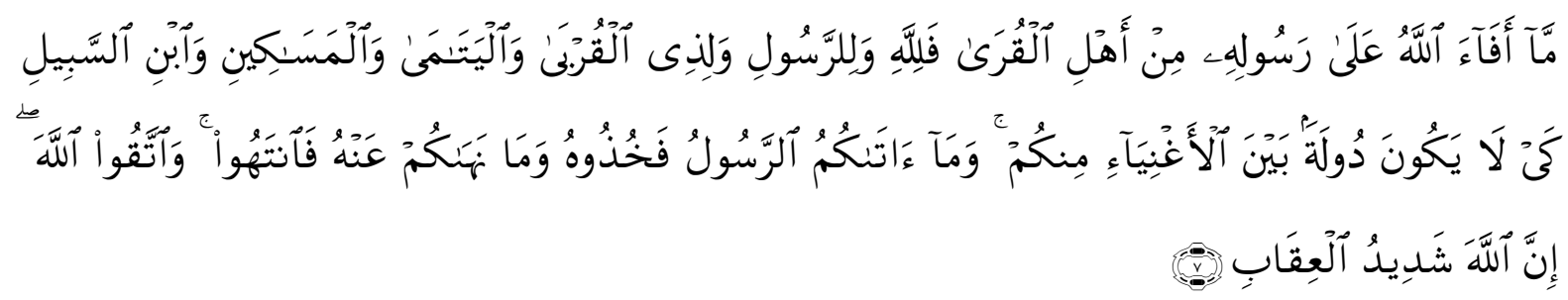

It means: "What are the spoils (fai-i) that Allah gave to His Messenger (from possessions) that came from the inhabitants of the cities? Then it is for Allah, for the apostles, relatives, orphans, poor people and those who are on the way, so that the treasure is not circulated among the Rich people among you, what the Apostle has given you, then accept it, and what it is forbidden for you, then leave it and fear God. the sentence.

2. The Hadith of the Prophet Muhammad SAW

In addition to the Qur ' an that explains the necessity to follow delivered by the Prophet, Hadith banya also describes the obligation for the Islamic Ummah to follow the teachings of the Prophet.

The following Hadith that explains the problem: 
Firmansyah

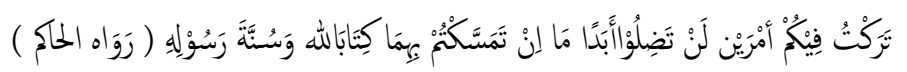

It means: "I am leaving two heirloom to you, if you cling to both, certainly will not get lost, which is the book of God and the Qur ' an and the Sunnah of His Messenger" (Reported by Al-Hakim)

The Hadith intimated to all Muslims to cling to tradition as well as sticking to the Qur ' an as views and legal sources bagikalangan akhlas especially educators and parents in educating negerasi Islamic easy and dignified.

3. Ijma'

All Muslims have agreed to practice the hadith. In fact, they consider it in line with fulfilling the call of Allah SWT, and His trusted Apostle. Muslims accept the Hadith as receive the Qur ' an as based on the affirmation of Allah, that tradition is one source of Islamic teachings. Allah also bore witness to the Prophet. that he only follows what is revealed. ${ }^{8}$

The Word of Allah SWT Surah Al An ' am Verse 50:

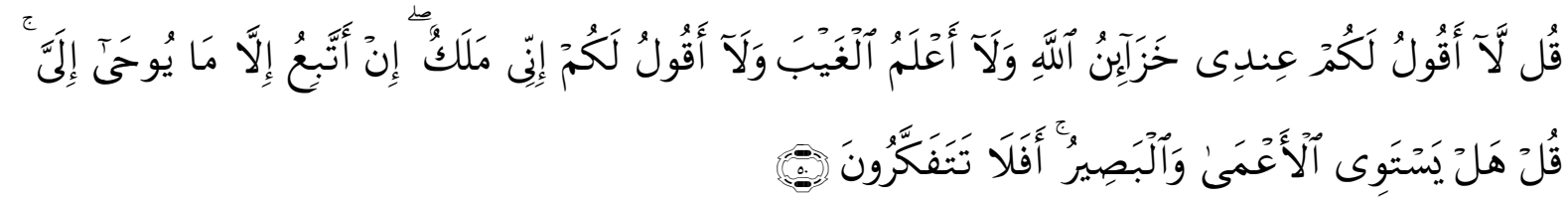

It means "Say: I do not tell you, that the treasury of God is upon me, and neither (nor) do I know the unseen or not (nor) I tell you that I am an angel. I do not follow except what is revealed to me. Say:" Do the same as the blind person who sees? "Then do you not think (of)?

\section{The source of moral education in the Hadith}

In Islam, the basic or gauges which states that the nature of the good or bad is the Qur an and Sunnah. Everything is good according to the Qur ' an and Sunnah, which is good and hold on in our daily lives. On the contrary, everything that is bad according to the Qur ' an and Sunnah, meaning not good and should be shunned.

Regarding the source of moral education can be seen from the following hadith.

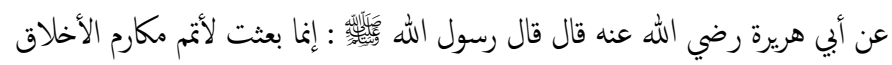

Meaning: Abu Hurairah Ra. "Narrate that the Prophet Muhammad. said "actually I was sent to perfect the morals".

From the above hadith's explanation that the improvement of morals is the mission of the Prophet Muhammad to send to the earth. According to him the glory of a person is not seen from the material but rather on the good or bad of one's morals, even the key to getting pleasure in the hereafter is the noble character taught by the prophets of the prophets.

\footnotetext{
${ }^{8}$ M. Agus Shalahuddin dan Agus Suyadi, Ulumul Hadis (Bandung: Pustaka Setia, 2008). 
Suyanto in his introduction in the book of Islamic Education explains that in the context of education, the hadith contains two cues. First, the main goal of education taught by the Prophet Muhammad is noble character education (karimah) and praiseworthy (mahmudah). Of course the source of morality here is what it says in al-Qur'an and Sunnah. Second, in the process of character education, he does not simply discard the traditions that are considered as good behavior according to the local community. That's why he uses the term "perfecting" instead of replacing. It can be concluded that the teachings of his manners are "maintaining good old ones and taking new better ones. ${ }^{9}$

Rasulullah SAW has shown noble character throughout his life. Al-Abrasyi stated that he was the kindest person in his behavior, the cleanest young man, the most zuhud man in his life, the fairest judge decided the case, the hero who was the most courageous in defending the truth, and the best example for pious people and educators. His personal character is a presentation in accordance with the Qur ' an. ${ }^{10}$

When asked about the morals of the Prophet Muhammad., Aisha said: قران خل قه كان means morality is arguably the Qur ' an. The purpose of Aisha's words was all the behavior and actions of the Prophet Muhammad. Both the enacting of the inner and always follow the instructions of the Qur ' an. Qur ' an always taught Muslims to do good and avoid bad deeds. Good and bad size is determined by the Qur ' an. The interests of morals in human life are clearly stated in the Qur'an.

Qur'an describes various approaches that put term Qur'an as a source of knowledge about the values and morals of the most obvious. Approach the Qur ' an in explaining the noble spirit, not a theoretical approach, but in the form of conceptual and appreciation. Noble character and a bad character portrayed in human temperament, the history and the reality of human life during the Qur ' an unloaded.

Qur'an describes the faith of the believers, their noble behavior, and their images were orderly, fair, noble. Inversely proportional to the ugliness and hypocrites who are ugly, unjust and humble. The picture of noble and vile characters is very clear in human behavior throughout history. Qur'an also describe the fighters apostles to uphold the values of noble and pure in life and when they are challenged by wickedness, disbelief and hypocrisy that thwart the establishment of a noble character as patio lives sublime and pure.

Allah SWT says in surah Al Maidah: 15 :

\footnotetext{
${ }_{9}^{9}$ Abdul Mujib dan Jusuf Mudzakkir, Ilmu Pendidikan Islam (Jakarta: Kencana Prenada Media, 2006), XV

${ }^{10}$ Bukhari Umar, Hadis Tarbawi Pendidikan dalam Perspektif Hadis (Jakarta: Amzah, 2014), 35-36.
} 
Firmansyah

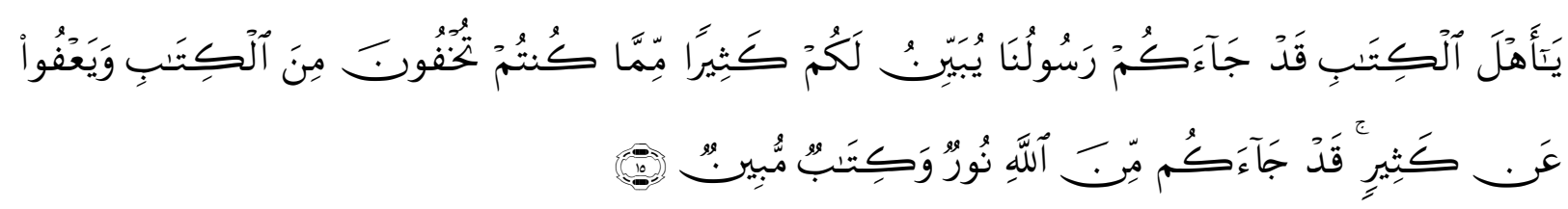

It means: "O People of the Book, Verily you have come to us Our Apostle, explained to you many of the contents of the book that you hid, and many (also) he let. Indeed has come to you the light of God, and the book that explains it. Allah guides those who follow His salvation to the way of salvation, and (with the same book) God takes these people out of complete darkness to a bright light with His permission, and guides them to the straight path. ${ }^{\text {ll }}$

So in the context of Islamic education, the person of the Prophet is the most appropriate example to be used as an example in shaping the person of the ummah who is moral .

The Word of Allah SWT surah Al Ahzab: 21

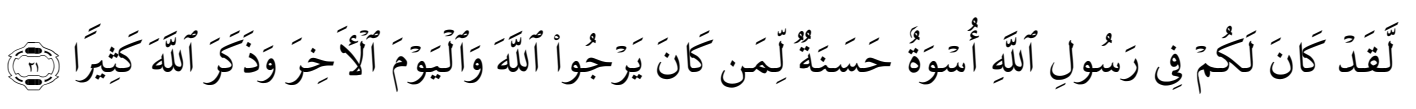

It means : "Indeed, the Prophet (s) is in heaven and is good for you (that is) to those who hope for (the mercy) of Allah and (the coming of) the Day of Resurrection and He often mentions Allah".

The fundamental purpose of the Prophet Muhammad. Since prophethood is expressly described in the Qur ' an:

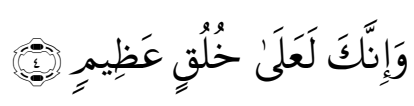

Meaning: "And indeed you are truly virtuous of great character"13

This shows that morality is an important role for every individual. In Islam, morality has a very important position as the most important element in religion, in this connection the Prophet Muhammad. Once asked, "What is religion?" He answered, "good morals" (Muslim HR). The importance of moral standing can be seen when seeing that the source of morality is revelation.

Morals provide an important role for life, both individual and collective. Takheran then if Qur'an emphasis to him. Qur'an laying the foundations of a noble, so Al Hadith have given quite a lot in the field portion of morals. According to one study, of the 60,000 hadiths, 20,000 pertain to creed, while the rest $(40,000)$ deal with morals and muamalah. It can be as evidence that Al Hadith, as the Qur'an, very concerned about morals. ${ }^{14}$

\footnotetext{
${ }^{11}$ Departemen Agama Republik Indonesia, Al-Qur'an dan Terjemahannya (Jakarta: Al-Huda, 2005).

${ }^{12}$ Indonesia.

${ }^{13}$ Indonesia.

${ }^{14}$ Anwar, Akhlak Tasawuf, 23.
} 


\section{E. Morals is the goal of Islamic education}

Moral education is the soul of Islamic education itself. Therefore, Islam has concluded that character education and morals are the spirit (soul) of Islamic education in achieving a perfect character is the true purpose of education. However, this does not mean we are not concerned with physical education or reason or science or other practical aspects, but rather that we actually pay attention to these other aspects. Children need strength in body, mind, knowledge, and also need character education, feelings, will, taste, and personality.

Basically there are two aspects of activities that are at the core of moral education. First, guiding students' consciences to develop more positively and gradually. The expected result is a change in the personality of students from being egocentric to altruistic. Second, fostering, developing and instilling positive values and attributes into the personalities of students, and together with the efforts to cultivate these positive values, moral education seeks to erode and distance students from bad traits and values. ${ }^{15}$

In relation to morality with the education of Dr. Muhammad Athiyyah Al Abrasyi, continued his remarks Islamic education experts have agreed that the purpose of Islamic education and teaching is not to fill the brains of students with all kinds of knowledge that they do not yet know but;

1. Educate their morals and souls.

2. Instill a sense of virtue (fadhilah)

3. Familiarize them with high courtesy

4. Prepare them for something of their holiness in all their lives with sincerity and honesty.

Thus, the main objective of Islamic education is to educate morals and soul formation. All subjects must contain moral lessons, every educator must think of religious morals and morals before the others because religious morals are the highest morals, while noble morals are the pillars of Islamic education. ${ }^{16}$

Imam Al Ghazali truly believes, "the purpose of education is to draw closer to Allah ' azza wa jalla, not rank and boast and a student should learn to seek rank, wealth, deceive fools or boast with friends." . So education is not out of moral education. Thus we can conclude that the main and main purpose of Islamic education is only in one sentence, namely fadhillah (virtue). ${ }^{17}$

Keep in mind that the real purpose of Islamic education is to form high morals and noble morals. The scholars and Muslim scholars with all their heart and attention try to instill noble

\footnotetext{
${ }^{15}$ Juwariyah, Dasar-Dasar Pendidikan Anak dalam al-Qur'an (Yogyakarta: TERAS, 2010), 13.

${ }^{16}$ Abrasyi, Prinsip-prinsip dasar pendidikan Islam.

${ }^{17}$ Abrasyi, 13-14.
} 


\section{Firmansyah}

morals, absorbing fadhilah into the souls of the prosecutors of knowledge, accustom them to hold to high morals and avoiding the things that are despicable, think in a physical and insaniyyah (clear humanity ), and use the time to study worldly sciences and religious sciences, regardless of material benefits.

Anyone who reads what is written by Muslim philosophers in education and morals, will always see this direction and how much they seek knowledge because of knowledge itself. In fact, they consider the task as a worship. They spend their lives researching and exploring to get to the nature and truth, without thinking about wealth, rank or position. Muslims glorify knowledge and scholars and the height of morals. Knowledge in their view is a valuable thing in this world, while the scholars who do good deeds are the inheritors of the prophets.

A person will not be able to carry out his mission or scientific tasks, unless he is sincere, ornate with high morals and noble, his soul is clean from all forms of manifestation. With the path of knowledge, good deeds, and good works, their hearts rise up to approach the Essence of the Creator, namely Allah SWT. ${ }^{18}$

The essence of education is to prepare and accompany someone in order to make progress and undergo perfection. Human needs for education vary as diverse human needs. He needs physical education to take care of his physique, he needs ethics education so he can maintain his behavior, he needs sense education so that his mind is healthy, he needs science education so that his knowledge is useful, he needs education in certain scientific disciplines in order to know nature, he needs education social so that he can socialize, he needs religious education to guide his spirit towards Allah, he also needs moral education so that his behavior is in tune with good morals.

Moral education is an adhesive thread that knits all types of education above. In other words, all types of education above must be subject to the principles of morals.

\section{F. Conclusion}

Islamic education is an integral and continuous education and covers all aspects of the scope of the human personality, especially the Islamic Ummah. One of the goals of Islam is to make people fearful, people who achieve the success of eternal life, in the world and in the hereafter. In addition, the purpose of Islamic education is an effort to prepare students to become Muslims who adjust their lives to the teachings of Islam that have moral values. Moral education is the subject of religious education material, because actually religion is morals, so the presence of the Prophet to the face of the earth in order to perfect human morals. Because religion is morals, it is no exaggeration to say that what is good according to morals is also

\footnotetext{
${ }^{18}$ Abrasyi, 22-23. 
good according to religion. Because of the large role of moral education in shaping the personality of human children, all Muslim philosophers agree that moral education is the soul and purpose of Islamic education. Because the highest goal of Islamic education is to educate the soul and character according to the guidance of the Prophet Muhammad SAW.

\section{Reference}

Abrasyi, Muhammad Athiyyah Al. Prinsip-prinsip dasar pendidikan Islam. Bandung: Pustaka Setia, 2003. Anis, Ibrahim. Al Mu'jam Al Wasith. Mesir: Dar Al Ma'arif, 1972.

Anwar, Rasihon. Akhlak Tasawuf. Bandung: Pustaka Setia, 2010.

Aslan. "Pumping Teacher dalam Tantangan Pendidikan Abad 21" 2, nomor 2 (2017): 89-100.

Indonesia, Departemen Agama Republik. Al-Qur'an dan Terjemahannya. Jakarta: Al-Huda, 2005.

Juwariyah. Dasar-Dasar Pendidikan Anak dalam al-Qur'an. Yogyakarta: TERAS, 2010.

Mujib, Abdul, dan Jusuf Mudzakkir. Ilmu Pendidikan Islam. Jakarta: Kencana Prenada Media, 2006.

Nata, Abudin. Akhlak Tasawuf. Jakarta: Rajawali Pers, 2012.

Shalahuddin, M. Agus, dan Agus Suyadi. Ulumul Hadis. Bandung: Pustaka Setia, 2008.

Umar, Bukhari. Hadis Tarbawi Pendidikan dalam Perspektif Hadis. Jakarta: Amzah, 2014. 